\title{
PENGEMBANGAN MODUL KETERAMPILAN DASAR KONSELING MAHASISWA
}

\author{
Panggih Wahyu Nugroho
}

Program Studi Bimbingan dan Konseling, Universitas Veteran Bangun Nusantara

Email:Panggih_wn@yahoo.com

\begin{tabular}{|c|c|}
\hline Article Info & Abstrak \\
\hline \multirow[t]{2}{*}{$\begin{array}{l}\text { Available online } \\
\text { 15.06.2019 }\end{array}$} & $\begin{array}{l}\text { Tujuan penelitian ini untuk mengembangkan modul ketrampilan dasar konseling. } \\
\text { Diharapkan hasil penelitian ini dapat secara efektif meningkatkan ketrampilan konseling } \\
\text { mahasiswa Binbingan dan Konseling Universitas Veteran Bangun Nusantara. Produk dari } \\
\text { penelitian ini berupa modul yang berisikan tentang ketrampilan dasar konseling. Dengan modul ini } \\
\text { diharapkan mahasiswa menjadi lebih mudah dalam memahami ketrampilan dasar konseling. } \\
\text { Penelitian ini menghasilkan Modul Ketrampilan Dasar Konseling Bagi Mahasiswa Universitas } \\
\text { Veteran Bangun Nusantara. Penelitian ini terdiri dari empat tahap yaitu penelitian awal, } \\
\text { perencanaan, dan pengembangan produk awal, uji kelayakan dan revisi produk. Pertama dilakukan } \\
\text { untuk merancang produk yang sesuai dengan kebutuhan. Tahap pertama yang dilakukan adalah } \\
\text { penelitian awal. Penelitian awal meliputi analisis kebutuhan, studi literatur, dan Merumuskan } \\
\text { masalah yang akan dipecahkan. Tahap kedua adalah perencanaan produk. Dalam tahap ini } \\
\text { dilakukan perancangan produk yang akan dijadikan modul ketrampilan dasar konseling bagi } \\
\text { mahasiswa. Tahap ketiga adalah pengembangan produk awal. Dalam tahap ini, langkah yang } \\
\text { dilakukan adalah menyediakan peta konsep produk terlebih dahulu sebagai kerangka atau } \\
\text { gambaran hasil produk. Tahap keempat adalah melakukan uji kelayakan produk. Pada tahap } \\
\text { ini produk awal diujikan kelayakannya melalui validasi ahli dan praktisi bimbingan dan konseling. } \\
\text { Setelah dilakukan validasi kemudian diadakan analisis hasil validasi. Hasil analisis validasi } \\
\text { tersebut kemudian menjadi landasan dalam revisi produk awal. Revisi produk awal dilakukan } \\
\text { untuk memperbaiki produk berdasarkan masukan para ahli dan praktisi, sehingga produk siap } \\
\text { untuk uji lapangan terbatas. } \\
\text { Kata kunci: modul, ketrampilan dasar konseling, konseling }\end{array}$ \\
\hline & $\begin{array}{l}\text { Abstract } \\
\text { The purpose of this study is to develop a module on basic counseling skills. It is expected that } \\
\text { the results of this study can effectively improve the counseling skills of Binbingan students and } \\
\text { Veteran Bangun Nusantara University Counseling. The product of this research is a module that } \\
\text { contains basic counseling skills. With this module it is expected that students will be easier to } \\
\text { understand basic counseling skills. This study resulted in the Basic Counseling Skills Module for } \\
\text { Students of the Veteran Bangun Nusantara University. This research consists of four stages, } \\
\text { namely initial research, planning, and initial product development, feasibility testing and product } \\
\text { revision. The first is done to design a product that fits your needs. The first step is the initial } \\
\text { research. Early research includes needs analysis, literature studies, and formulating problems to } \\
\text { be solved. The second stage is product planning. In this stage the product design is carried out } \\
\text { which will be used as a basic counseling skills module for students. The third stage is the initial } \\
\text { product development. In this stage, the step taken is to provide a product concept map first as a } \\
\text { framework or an overview of product results. The fourth stage is to conduct product feasibility } \\
\text { tests. At this stage the initial product is tested for its feasibility through expert validation and } \\
\text { guidance and counseling practitioners. After validation, an analysis of the validation results is } \\
\text { then carried out. The results of the validation analysis then become the foundation in the initial } \\
\text { product revision. The initial product revision is done to improve the product based on input from } \\
\text { experts and practitioners, so that the product is ready for limited field testing. } \\
\text { Keyword: modules, basic counseling, counseling skills }\end{array}$ \\
\hline
\end{tabular}

\section{PENDAHULUAN}

Bimbingan dan Konseling di Indonesia telah berkembang sejak pertama kali dikenalkan pada awal tahun 1960. Kemudian lebih dimantapkan dengan dimasukannya Bimbingan dan Konseling 
pada kurikulum 1975 menjadikan Bimbingan dan Konseling tidak terpisahkan dari proses pendidikan di Indonesia. Kemudian Prayitno menjelaskan bahwa perkembangan Bimbingan dan Konseling dibagi penjadi 5 periode yaitu periode I dan II prawacana dan pengenalan (tahun 1960-1970), periode III pemasyarakatan (1970-1990-an), periode IV konsolidasi (1990-2000), dan periode V lepas landas $(>2000)$.

Periode lepas landas merupakan periode modern pada perkembangan Bimbingan dan Konseling di Indonesia. Menurut Yusuf (2010) Pada periode ini terjadi beberap hal penting antara lain yaitu lahirnya UU No.20 Tahun 2003 yang didalamnya termuat ketentuan bahwa konselor merupakan salah satu jenis tenaga pendidik, munculnya standarisasi profesi konseling, serta kerjasama Asosiasi Bimbingan dan Konseling Indonsia dengan Direktorat PLP dalam merumuskan kompetensi guru pembimbing SMP dan sekaligus memberikan pelatihan kepada mereka.

Seorang pendidik harus memiliki kualifikasi akademik dan kompetensi sebagai agen pembelajaran, sehat jasmani dan rohani serta memiliki kemampuan untuk mewujudkan tujuan pendidikan nasional. Kompetensi sebagai agen pembelajaran pada jenjang pendidikan dasar dan menengah serta pendidikan anak usia dini meliputi kompetensi pedagogik, kompetensi kepribadian, kompetensi profesional, dan kompetensi sosial. Kompetensi adalah sebuah kontinum perkembangan mulai dari proses kesadaran, akomodasi. Kompetensi merupakan komponen utama dari standar profesi yang dimaknai sebagai perangkat perilaku efektif yang terkait dengan eksplorasi dan investigasi, menganalisis, dan memikirkan serta memberikan perhatian dan mempersepsi yang mengarahkan seseorang menemukan cara-cara untuk mencapai tujuan tertentu secara efektif dan efisien.

Sebagai pendidik psikologis konselor berperan dan berfungsi sebagai seorang pendidik psikologis yang harus menguasai kompetensi-kompetensi dalam hal Penguasaan konsep dan praksis pendidikan, Kesadaran dan komitmen etika profesional, Penguasaan konsep perilaku dan perkembangan individu, Penguasaan konsep dan praksis assesmen, Penguasaan konsep dan praksis bimbingan dan konseling, Pengelolaan program bimbingan dan konseling, Penguasaan konsep dan praksis riset dalam bimbingan dan konseling. Ketujuh kompetensi konselor tersebut merupakan komponen-komponen kompetensi Konselor yang harus dimiliki konselor dalam melakukan tugas sehari-hari.

Untuk menjadi pengampu pelayanan di bidang bimbingan dan konseling, tidak dikenal adanya pendidikan profesional konsekutif sebagaimana yang berlaku di bidang pendidikan profesional guru. Kompetensi akademik seorang Konselor Profesional terdiri atas kemampuan 1) Menguasai secara akademik teori, prinsip, teknik dan prosedur pelayanan bimbingan dan konseling, 2) Mengemas teori, 
prinsip, teknik dan prosedur pelayanan bimbingan dan konseling tersebut sebagai materi pembelajaran.

Mahasiswa Bimbingan dan Konseling sebagai seorang calon Konselor maka perlu menguasai ketrampilan dasar konseling. Ketrampilan dasar konseling tersebut dapat digunakan sebagai dasar pengusaan teknik maupun prosedur pelayanan konseling. Karena pentingnya ketrampilan dasar konseling maka perlu pengembangan ketrampilan dasar konseling.

Nelson dan Jones (2012) menjelaskan konseling merupakan suatu representasi langkah demi langkah yang disederhanakan dari berbnagai tujuan dan kegiatan yang berbeda di tahap-tahap progesif. Kemudian dijelaskan lebih lanjut ada tiga tahap dasar proses konseling. Ketiga tahap tersebut dapat disebut sebagai Relating-Understanding-Changing (RUC).

\section{Relating}

Pada tahap ini konselor membangun huhubungan kerja dengan konseli. Konselor akan membangun kepercayaan konseling dan konseli akan berusaha percaya terhadap konselor. Beberapa ketrampilan yang dikembangkan pada tahap ini yaitu memahami kerangka acuan internal, menunjukan perhatian dan ketertarikan, merefleksikan perasaan, memulai proses konseling, dan menanggulangi resistensi dan membuat rujukan

\section{Understanding}

Tugas utama pada tahap ini adalah mengases dan menyetujui definisi yang disepakati bersama tentang masalah klien. Beberapa ketrampilan yang dikembangkan pada tahap ini yaitu mengases perasaan dan reaksi fisik; mengases pikiran; mengases komunikasi dan tindakan; tantangan,umpan balik, dan pengungkapan diri; memonitor, merangkum, sdan ketrampilan mengidentifikasi.

\section{Changing}

Tugas utama pada tahap ini yaitu membantu konseli untuk berubah sehingga masalah dan problem situations ditangani dengan lebih efektif. Beberapa ketrampilan yang dikembangkan pada tahap ini yaitu membantu mengatasi masalah; ketrampilan coaching (berbicara, mendemonstrasikan, dan memngulang-ulang latihan); memperbaiki komunikasi dan tindakan; memperbaiki pemikiran; menegosiasikan pekerjaan-rumah; melaksanakan sesi-sesi pertengahan; mengakhiri konseling.

Modul merupakan salah satu metode pengajaran yang selama ini telah dikembangkan oleh para ahli. Menurut Nana Sudjana dan Ahmad Rivai (2003: 132), modul merupakan suatu unit program pengajaran yang disusun dalam bentuk tertentu untuk keperluan belajar. modul adalah paket pengajaran instruksional yang dipelajari oleh individu sendiri secara perorangan atau diajarkan oleh pandidik kepada dirinya sendiri. Modul berisi rangkaian kegiatan belajar yang dirancang secara 
sistematik, Tujuan belajar yang dirumuskan secara jelas dan khusus, sehingga memungkinkan individu dapat belajar sendiri (Independent).

\section{METODE PENELITIAN}

Pendekatan yang digunakan dalam penelitian ini adalah pendekatan penelitian dan pengembangan (research and development). Pengembangan merupakan suatu proses menterjemahkan spesifikasi desain kedalam suatu wujud fisik tertentu. Menurut Sugiyono (2010:407), metode penelitian dan pengembangan merupakan metode yang digunakan untuk menghasilakn produk tertentu, dan menguji keefektifan produk tersebut. Dasar pertimbangan penggunaan pendekatan ini adalah pendapat Borg dan Gall (2007:775) yang menyatakan bahwa bahwa strategi penelitian dan pengembangan efektif untuk mengembangkan dan memvalidasi produk.

\section{HASIL DAN PEMBAHASAN}

Penelitian awal atau yang disebut juga dengan penelitian pendahuluan bertujuan untuk mengumpulkan berbagai data untuk melengkapi data yang diperlukan. Data tersebut berfungsi sebagai landasan utama dalam membuat instrumen pengukur kebiasaan belajar siswa. Kegiatan yang dilakukan dalam penelitian awal dan pengumpulan informasi yaitu sebagai berikut:

\section{Analisis kebutuhan}

Tahap pertama dari penelitian ini adalah analisis kebutuhan. Tahap ini diperlukan untuk melihat apakah modul keterampilan dasar konseling dibutuhkan oleh mahasiswa Program Studi Bimbingan dan Konseling Universitas Veteran Bangun Nusantara atau tidak. Analisis kebutuhan menggunakan metode wawancara kepada mahasiswa. Berdasarkan hasil wawancara secara random, diketahui bahwa mahasiswa membutuhkan suatu modul yang digunakan sebagai pedoman dalam meningkatkan keterampilan dasar konseling mahasiswa Program Studi Bimbingan dan Konseling Universitas Veteran Bangun Nusantara

\section{Studi literatur}

Setelah peneliti melakukan penelitian awal, peneliti melakukan studi literatur dengan mempelajari literatur bacaan yang relevan dengan variabel penelitian yaitu literatur yang berhubungan dengan keterampilan dasar konseling. Adapun literatur yang berhubungan dengan materi keterampilan dasar konseling. Untuk mendukung asumsi pengembangan produk digunakan jurnal serta hasil penelitian sebelumnya yang dilakukan oleh peneliti lain. 


\section{Perencanaan}

Modul yang dikembangkan berupa modul keterampilan dasar konseling. Pengembangan produk ini berdasarkan studi pendahuluan yang mendapatrkan hasil adanya kebutuhan mahasiswa terkait pengembangan keterampilan dasar konseling. Materi yang digunakan dalam mengembangkan produk didapatkan dari hasil studi literatur. Hasil penelitian awal tersebut melandasi dikembangkannya produk instrumen ini.

Berdasarkan hasil studi literatur didapatkan hasil berupa materi yterkait keterampilan dasar konseling. Materi tersebut kemudian dikembangkan menjadi modul. Di dalam modul tersebut disertakan penjelasan ringkas, contoh, serta latihan yang dapat dilakukan oleh siswa dalam mengembangkan keterampilan dasar konseling.

\section{Pengembangan produk awal}

Pengembangan modul keterampilan dasar konseling untuk mahasiswa Univet Bantara dilakukan melalui beberapa tahapan, diantaranya adalah: 1) Mengumpulkan materi dan bahan mengenai keterampilan dasar konseling, 2) menentukan isi materi modul, 3) membuat draft mentah, 4) membuat lay out isi modul, 6) membuat cover modul, 7) mencetak buku.

Hasil yang diperoleh adalah modul keterampilan dasar konseling untuk mahasiswa. Modul tersebut berisi materi keterampilan dasar konseling dengan pendekatan RUC (RelatingUnderstanding-Changing) yang merupakan metode yang dikemukakan oleh Nelson-Jones. Metode ini dianggap lebih efektif digunakan karena telah mencakup dari awal sesi konseling hingga proses menutup sesi konseling.

\section{Uji lapangan awal}

Uji kelayakan terhadap modul keterampilan dasar konseling untuk mahasiswa bertujuan untuk memantapkan kesesuaian dan kelayakan modul yang telah disusun. Proses uji kelayakan dimaksudkan untuk memantapkan; 1) kelengkapan dan keutuhan model; dan 2) kelayakan model yang telah dirumuskan untuk diterapkan.

Uji kelayakan dasar modul keterampilan dasar konseling terdiri dari uji ahli dan juga uji praktisi. Uji ahli dilakukan oleh dua orang ahli dalam layanan bimbingan dan konseling dan ahli pengembangan teknologi pendidikan. Berdasarkan validasi pada modul keterampilan dasar konseling, validator ahli materi memberikan beberapa saran/ masukan, antara lain: 1) perbaikan terkait dengan tata tulis yang masih terdapat beberapa kesalahan, 2) kesimpulan terhadap validasi skala yaitu dapat digunakan dengan sedikit revisi. Berdasarkan validasi pada modul keterampilan dasar konseling, validator ahli Media memberikan beberapa saran/masukan, antara lain: 1) beberapa 
butir pernyataan belum mengikuti kaidah bahasa Indonesia yang baik, 2) kesimpulan terhadap validasi skala yaitu dapat digunakan dengan sedikit revisi.

\section{Hasil pengembangan model}

Dalam mengembangkan modul, kerangka modul adalah modal utama yang sangat penting sebagai dasar pembuatan modul. Kerangka modul Keterampilan dasar Konseling yaitu sebagai berikut:

\section{Menetapkan (menggariskan) tujuan intruksional umum (TIU)}

Keterampilan Dasar Konseling yang dikembangkan adalah dengan pendekatan RUC. Berdasarkan pendekatan tersebut, tujuan intruksional umumpada modul ini yaitu memahami hakikat ketrampilan dasar konseling, memahami tentang menjalin hubungan dengan konseli, Memahami tentang memahami konseli, dan Memahami tentang konsep mengubah konseli.

\section{Merumuskan Tujuan Intruksional Khusus (TIK) yang merupakan perincian atau pengkhususan dari tujuan intruksional umum tadi,}

Berdasarkan TIU modul keterampilan dasar, maka TIK dari setiap TIU tersebut adalah sebagai berikut pertama Memahami Hakikat Ketrampilan Dasar Konseling yaitu Memahami tentang menciptakan komunikasi verbal, Memahami tentang menciptakan komunikasi vokal, Memahami tentang menciptakan komunikasi tubuh. Kedua Memahami tentang menjalin hubungan dengan konseli yaitu Memahami kerangka acuan konseli, Memahami tentang menunjukan perhatian dan ketertarikan kepada konseli, Memahami tentang merefleksikan perasaan, Memahami tentang memulai proses konseling, Memahami tentang menanggulangi resistensi dan membuat rujuan untuk konseli. Ketiga memahami tentang memahami konseli yaitu Memahami tentang mengases perasaan dan reaksi fisik, Memahami tentang mengases pikiran, Memahami tentang mengases komunikasi dan tindakan, Memahami tentang tantangan, umpan balik dan pengungkapan diri, Memahami tentang memonitor, merangkum, dan ketrampilan mengidentifikasi. Ketiga Memahami tentang konsep mengubah konseli yaitu Memahami tentang membantu mengatasi masalah, Memahami tentang ketrampilan coaching, Memahami tentang memperbaiki komunikasi dan tindakan, Memahami tentang memperbaiki pikiran, Memahami tentang mengakhiri konseling

\section{Menyusun soal-soal penilaian untuk mengukur sejauh mana tujuan intruksional khusus bisa} dicapai,

Soal-soal penilaian yang digunakan untuk mengevaluasi pencapaian hasil belajar modul oleh mahasiswa adalah pertama BAB 1 Pendahuluan, Soal-soal dan tugas yang digunakan pada bab ini 
yaitu Jelaskan pengertian Ketrampilan Dasar Konseling, Dengan cara berpasangan lakukan komunikasi verbal, kemudian evaluasi apakah komunikasi tersebut telah berjalan dengan baik aatu tidak !, dengan cara berpasangan lakukan komunikasi vokal, kemudian evaluasi apakah komunikasi tersebut telah berjalan dengan baik aatu tidak !, Dengan cara berpasangan lakukan komunikasi tubuh, kemudian evaluasi apakah komunikasi tersebut telah berjalan dengan baik aatu tidak !

Kedua adalah Bab 2 Relating, Soal-soal dan tugas yang digunakan pada bab ini yaitu Dengan cara berpasangan, lakukan wawancara sehingga menemukan kerangka acuan konseli dari pasangan anda tersebut!, Dengan cara berpasangan lakukan menunjukan perhatian dan ketertarikan kepada konseli., kemudian evaluasi apakah kegiatan tersebut telah berjalan dengan baik aatu tidak !, Dengan cara berpasangan lakukan merefleksikan perasaan, kemudian evaluasi apakah kegiatan tersebut telah berjalan dengan baik aatu tidak !, Dengan cara berpasangan lakukan kegiatan awal memulai proses konseling, kemudian evaluasi apakah kegiatan tersebut telah berjalan dengan baik atau tidak !, Dengan cara berpasangan lakukan kegiatan menanggulangi resistensi dan membuat rujukan untuk konseli, kemudian evaluasi apakah kegiatan tersebut telah berjalan dengan baik atau tidak !

Ketiga adalah Bab 3 Understanding, Soal-soal dan tugas yang digunakan pada bab ini yaitu Dengan cara berpasangan, lakukan wawancara sehingga memahami perasaan dari pasangan anda tersebut!, Dengan cara berpasangan lakukan mengases perasaan dan reaksi fisik, kemudian evaluasi apakah kegiatan tersebut telah berjalan dengan baik aatu tidak !, Dengan cara berpasangan lakukan mengases pikiran, kemudian evaluasi apakah kegiatan tersebut telah berjalan dengan baik aatu tidak !, Dengan cara berpasangan lakukan kegiatan mengases komunikasi dan tindakan, kemudian evaluasi apakah kegiatan tersebut telah berjalan dengan baik atau tidak !, Dengan cara berpasangan lakukan kegiatan tantangan, umpan balik dan pengungkapan diri, kemudian evaluasi apakah kegiatan tersebut telah berjalan dengan baik atau tidak !, Dengan cara berpasangan lakukan kegiatan memonitor, merangkum, dan ketrampilan mengidentifikasi, kemudian evaluasi apakah kegiatan tersebut telah berjalan dengan baik atau tidak !

Keempat Bab 4 Changing, Soal-soal dan tugas yang digunakan pada bab ini yaitu Dengan cara berpasangan, lakukan wawancara sehingga memahami permaslahan apa yang perlu dirubah dari pasangan anda tersebut!, Dengan cara berpasangan lakukan men membantu mengatasi masalah, kemudian evaluasi apakah kegiatan tersebut telah berjalan dengan baik aatu tidak !, Dengan cara 
berpasangan lakukan ketrampilan coaching, kemudian evaluasi apakah kegiatan tersebut telah berjalan dengan baik aatu tidak !, Dengan cara berpasangan lakukan kegiatan memperbaiki komunikasi dan tindakan, kemudian evaluasi apakah kegiatan tersebut telah berjalan dengan baik atau tidak !, Dengan cara berpasangan lakukan kegiatan memperbaiki pikiran, kemudian evaluasi apakah kegiatan tersebut telah berjalan dengan baik atau tidak !, Dengan cara berpasangan lakukan kegiatan mengakhiri konseling, kemudian evaluasi apakah kegiatan tersebut telah berjalan dengan baik atau tidak!

\section{Identifikasi pokok-pokok materi pelajaran sesuai dengan setiap tujuan intruksional khusus,}

Pokok-pokok materi yang digunakan untuk memenuhi TIK pada modul keterampilan dasar konselinmg adalah sebagai berikut pertamaBab 1 Pendahuluan. Untuk memenuhi TIK pada tahap pendahuluan atau pra konseling yaitu dengan memberikan materi berikut ini Hakikat Keterampilan Dasar Konseling, Menciptakan keterampilan verbal, Menciptakan keterampilan vokal, Menciptakan keterampilan komunikasi tubuh, Menciptakan keterampilan pikiran

Kedua Bab 2 Relating, untuk memenuhi TIK pada tahap relating atau menjalin hubungan dengan konseli yaitu dengan memberikan materi berikut ini Memahami kerangka acuan internal konseli, Menunjukan perhatian dan ketertarikan, Merefleksikan perasaan, Memulai proses konseling, Menanggulangi resistensi dan membuat rujukan

Ketiga Bab 3 Understanding, untuk memenuhi TIK pada tahap understanding atau memahami konseli yaitu dengan memberikan materi berikut ini Mengases perasaan dan reaksi fisik, Mengases pikiran, Mengases komunikasi dan tindakan, Tantangan, umpan balik dan pengungkapan diri, Memonitor, merangkum, dan ketrampilan mengidentifikasi

Keempat Bab 4 Changing, untuk memenuhi TIK pada tahap chaging atau mengubah konseli yaitu dengan memberikan materi berikut ini membantu mengatasi masalah, Memahami tentang ketrampilan coaching, Memahami tentang memperbaiki komunikasi dan tindakan, Memahami tentang memperbaiki pikiran, Memahami tentang mengakhiri konseling

\section{KESIMPULAN DAN SARAN}

Berdasarkan hasil penelitian diambil simpulan yaitu modul yang disusun berdasarkan penelitian pustaka meliputi empat tahap yaitu tahap pendahuluan, tahap relating, tahap understanding serta tahap changing. Dalam empat tahap tersebut terdiri berbagai keterampilan yang mendukung proses konselinng yang memamndirikan. 


\section{DAFTAR PUSTAKA}

Borg, W.R. \& Gall, M.D. (2007). Educational Research: An Introduction( $\left.4^{\text {th }} e d\right)$. New York \& London: Longman.

Depdiknas. (2008). Penataan Pendidikan Profesional Konselor dan Layanan Bimbingan dan Konseling Dalam Jalur Pendidikan Formal. Bandung: FIP-UPI

Oxford. (2003). Oxford Learner's Pocket Dictionary. New York: Oxford University Press.

Smaldino, S.E., Lowther, D.L., dan Russell, J.D. (2011). Instructional Technology \& Media For Learning,Teknologi pembelajaran dan media untuk belajar (Arif Rahman Terjemahan). Jakarta: Kencana Prenada Media Group Sugiyono. (2010). Metodologi Penelitian Kuantitatif Kualitatif dan R\&D. Bandung: Alfabeta 